by which the people of Missouri are frequently designated even to this day. The judge wrote a series of lively letters to other Iowa papers signed "A Wolverine Among the Hawkeyes," referring Iowans thus, which were widely read, quoted and commented upon.

The nickname received formal approval at a meeting of prominent state officials and others who gathered at the rooms of Governor Lucas in the Burlington House in the fall of 1838. Among those present besides Lucas were: W. B. Conway, territorial secretary; Ver Planck Van Antwerp, receiver of public moneys; Joseph Williams, supreme court justice; T. S. Parvin and Jesse Williams, secretaries and aides of the governor, and James G. Edwards. The matter of perpetuating a nickname for Iowa was discussed. After various sobriquets were mentioned, "Hawkeye" was proposed and all agreed upon its appropriateness.

\title{
Burlington Rated Several "Firsts"
}

The city of Burlington has a distinguished place, not only in the early history of the state of Iowa, but also in the history of the settlement of the Middle West as a whole. Long before it became a white man's town, it had been an Indian center and for that reason became at a very early time an important trading-post.

After the Middle West began to be organized, the area in which Burlington stood belonged to the vast territory of Michigan; and when a large portion of the latter was cut off to form the territory of Wisconsin the whole of Iowa was included in it.

Wisconsin held its first territorial legislature in 1836, at Belmont, and during its sessions Madison was selected as the first capital. But the necessary public buildings at Madison were not completed-they could not be until 1839-therefore the new legislature met at Burlington, the first meeting on November 6, 1837, the second on June 11, 1838. Thus it was that Burlington became for a brief period the capital of a territory, 
out of which the states of Iowa, Wisconsin, Minnesota, and North and South Dakota later were carved.

For such reasons it was historically fitting that the first Masonic lodge in the territory of what is now the state of Iowa should be organized in Burlington. Theodore Parvin described the event at length and in detail in an article contributed by him in The Evergreen Magazine, in 1868, which was only three years after the end of the Civil war.-H. L. Haywood in Masonic Grand Lodge Bulletin.

\section{Jefferson Advocated Economy}

I place economy among the first and most important virtues, and public debt as the greatest of dangers to be feared. To preserve our independence, we must not let our rulers load us with perpetual debt. We must make our choice between economy and liberty, or profusion and servitude. If we run into such debts we must be taxed in our meat and drink, in our necessities and in our comforts, in our labors and in our amusements. If we can prevent the government from wasting the labors of the people under the pretense of caring for them, they will be happy. The same prudence which in private life would forbid our paying our money for unexplained projects, forbids it in the disposition of public money.-Thomas Jefferson, (1816).

\section{Deadwood Dates "Wild Bill" Hickok}

Up at Deadwood, South Dakota on June 21, 1951, occurred the dedication of a twice-life size Black Hills granite bust of James Butler "Wild Bill" Hickok, the unique character that gave that area much of its color in the early days. The gift of George Hunter, a prominent Deadwood citizen, the heroic figure is the work of sculptor Korczak Ziolkowski. The occasion marked the seventy-fifth anniversary of the arrival of "Wild Bill" and his party in Deadwood, as well as the year of the gold rush to that locality. 
Copyright of Annals of Iowa is the property of State of Iowa, by \& through the State Historical Society of Iowa and its content may not be copied or emailed to multiple sites or posted to a listserv without the copyright holder's express written permission. However, users may print, download, or email articles for individual use. 